\title{
27. 新潟県大汇鉱山のスイマンガン鉱
}

\author{
Manganite from Oyé Mine, Niigata Prefecture
}

\section{高須新一郎 (Shin-ichiro Takasu)}

大江鉱山は新潟県南蒲原郡下田村大江 (旧森町村) 飞西り, 第三系のギョ ウカイ岩中に胚胎する酸化マンガンを採掘している。ての酸化マンガンは桃

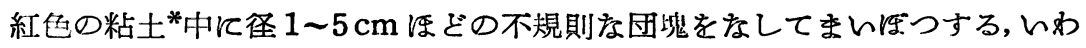
ゆる芓マンガンで, やや褐色味をおびた灰黒色を呈し，ちみつ質ですてぶる 堅硬である。団塊の表面はしばしば凹凸が著しく，中にはスラッグ状を呈す るものさえ見られるが, 注意して観察すれば三角形に輝やくきわめて微細な 結晶粒をみとめるてとができる。塊を切断すると内部に多くの小空洞が散在

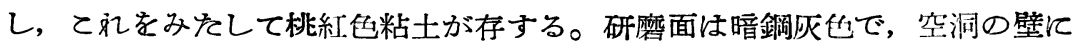
そつて累带がみとめられ，その部分はやや透明な観を有する。顕微鏡下では 自形または半自形の集合体で明らかな消光を示し，多色性は暗灰色一青灰色 -一淡黄灰色で西る。

結晶は八面体て似た錐形の結晶で径 $0.5 \mathrm{~mm}$ 内外である。条痕は赤褐色， 硬度 5 度，すこぶる堅固でハンマーで容易にわれない。比重 4. 32 . 均一と 思われる部分をとり分析した結果任第1禀のとおりである。不純物をのぞき 主要成分によつて化学式を作ると涯在４ $4 \mathrm{MnO} \cdot 3 \mathrm{MnO}_{2} \cdot 4 \mathrm{H}_{2} \mathrm{O}$ となり，スイ マンガン鉱の $\mathrm{MnO}(\mathrm{OH})$ 飞近い。

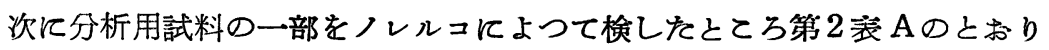
で, てれと対比した ASTM カード中のスイマンガン鉱のパターンによく一 致する。

桜井欽一，南部松夫，金子美道等によれば，かが国のスイマンガン鉱と称 するものの5ち, パイロルース鉱に変質し，スイマンガン鉱後の仮晶をなす パイロルース鉱が相当多く存する由であるが**，本鉱物はまだ変質をらけて おらねスイマンガン鉣である。

* モンモリロン石采鉱物からなり少量の炭酸塩鉱物を含んでいる。

**たとえば北海道湯ノ沢鉱山, 青森県早瀬野鉱山, 新潟県広谷等はスイマンガン鉱後 のパイロルース鉱に属する。 
第 1 表 大江鉱山産スイ

マンガン鉱の化学組成

\begin{tabular}{l|c}
$\mathrm{MnO}$ & $72.63 \%$ \\
$\mathrm{O}$ & 9.08 \\
$\mathrm{SiO}_{2}$ & 3.50 \\
$\mathrm{Al}_{2} \mathrm{O}_{3}$ & 痕跡 \\
$\mathrm{Fe}_{2} \mathrm{O}_{3}$ & 0.22 \\
$\mathrm{CaO}$ & 0.04 \\
$\mathrm{MgO}$ & 痕跡 \\
$\mathrm{BaO}$ & 1.33 \\
$\mathrm{H} 2 \mathrm{O}(+)$ & 12.92 \\
$\mathrm{H}_{2} \mathrm{O}(-)$ & 0.32 \\
\hline 訫 & $100.04 \%$ \\
\hline
\end{tabular}

長島秀夫分析

（1954年）
第 2 表

スイマンガン鉱の $\mathrm{X}$ 線粉末線

\begin{tabular}{rc|cc}
\hline \multicolumn{2}{c|}{ (A) } & 大江産* & (B) ASTM カード \\
\cline { 2 - 4 }$I$ & $d(\AA)$ & $I$ & $d(\AA)$ \\
\hline 150 & $3.40_{4}$ & 100 & 3.40 \\
28 & $2.69_{6}$ & 80 & 2.65 \\
8 & $2.53_{0}$ & 40 & 2.52 \\
34 & $2.41_{9}$ & 80 & 2.41 \\
20 & $2.27_{2}$ & 60 & 2.26 \\
15 & $2.20_{0}$ & 60 & 2.18 \\
5 & $1.84_{4}$ & & \\
18 & $1.78_{3}$ & 80 & 1.77 \\
8 & $1.70_{5}$ & 70 & 1.70 \\
\hline
\end{tabular}

* $\mathrm{Fe} K .30 \mathrm{kV}, 9 \mathrm{~mA}, 81-4$, 1-0.006-1, $2^{\circ} / \mathrm{sec}$.

終りに匭ふ御指導いただんた渡辺武男, 櫻井欽一両博士, ならびに分析の 労をとられた日本電興株式会社の長島秀夫氏に深謝する。

\section{8. 稫島県水晶山產アブクマ石*}

Abukumalite from Suishôyama, Fukushima Prefecture

$$
\text { 櫻 井 欽 一 (Kin-ichi Sakurai) }
$$

福島県伊達郡川俣町 (旧领坂村) 関ノ上にある水晶山のペグマタイト中よ り種及の希元素鉱緆を産し, 科学研究所の旧飯盛研究室はじめ東北大学の岩 石鉱物鉱床学教室によつていろいろの研究が行われた。アブクマ石注畑晋に

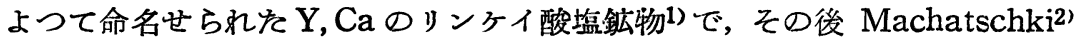
はこれをリンカイ石族の鉱物と考え,イットロケイ酸リンカイ石とした。一 方犬塚英夫は， $\mathrm{X}$ 線的研究によつて，乙の鉱紩が六方晶系に属しリンカイ石 に近ん構造をもつものであるてとを指摘しだ”。最近では大森啓一，長谷川

* 阿武隈石 $(\mathrm{Ca}, \mathrm{Y})_{5}(\mathrm{OH})(\mathrm{Si}, \mathrm{P})_{3} \mathrm{O}_{12}$

1) S. Hata: Sci. Pap. Inst. Pys. Chem. Res., 34, 455, 1018 (1938).

2) F. Machatschki : Zbl. Min., 161 (1939).

3）当時の談話による (1939 年), 未発表。 